\title{
AJKAY ALINKA
}

\section{„A' Magyar Nyelvnek polgári nyelvvé emelése felől” \\ Kazinczy pályamüvének kiadás-, kutatás- és recepciótörténete}

Idén százegy éve annak, hogy Kazinczy Ferenc Tübingai pályamüvének egyetlen teljes szövegkiadása megjelent. ${ }^{1}$ Kazinczy életművének kutatása már jóval korábban elkezdödött, $\mathrm{s}$ halálának évszázados jubileuma újabb lendületet adott neki, ami azóta is töretlen, a jelenleg is folyó kritikai kiadás munkálatai pedig nyilvánvalóan tovább fogják gyarapítani a felvilágosodás magyar vezéregyénisége életére és életmüvére vonatkozó ismereteinket. Nem véletlenül tünik tehát úgy, hogy a szakirodalomban régóta megszilárdult, az egymást követő kutatógenerációkon átöröklődött vélekedések és tényként kezelt állítások is érdemesek arra, hogy újra megvizsgáljuk és számba vegyük őket, hiszen - ahogy arra a jelen tanulmány is bizonyítékot kínál - a hosszú kutatástörténet során olyan megállapítások tünhettek el a kutatói vizsgálódás látóhatáráról, vagy olyan felismerések maradtak teljesen ismeretlenek, amelyek fontos meglátásokat tartalmaznak, és amelyek érdemesek a továbbgondolásra, és hogy visszakerüljenek a Kazinczykutatás szakirodalmának kánonjába.

A szakirodalom Kazinczy Ferenc Tübingai pályamüve megírásának körülményeit elsősorban Heinrich Gusztáv szövegkiadása és elemzése alapján ismeri, és az általa felállított keretek között fogadja el. Ha azonban újra áttekintjük kiadásának kortárs recepcióját, kritikai visszhangját, illetve ezzel párhuzamosan végigkövetjük a Kazinczy-kéziratok sorsát és történetüket, Heinrich számos megállapítása kétségessé és nehezen igazolhatóvá válik.

A Tübingai pályamünek (1808) jelenleg két kézirata ismert: az egyik az Akadémia kézirattárában örzött kétnyelvü példány (bilingvis), ${ }^{2}$ a másik pedig egy csak a magyar szöveget tartalmazó kézirat, amely a debreceni Déri Múzeumban található. ${ }^{3}$ Kazinczy életében a pályamü teljes szövege sem magyarul, sem németül nem jelent meg nyomtatásban, mindössze az írás harmadik részében található irodalmi szöveggyüjtemény látott napvilágot 1814-ben kétszer is. Az Erdélyi Múzeumban a magyar szöveg jelent meg, ${ }^{4}$ a bécsi Allgemeine Literatur-

\footnotetext{
${ }^{1}$ Kazinczy Ferenc tübingai pályamüve a magyar nyelvről 1808, kiad. Heinrich Gusztáv, Bp., 1916.

${ }^{2}$ MTAK Kézirattár, Magy. Nyelvtud. 40 42/I.

${ }^{3}$ Déri Múzeum Irodalmi Kéziratos Gyüjteménye X. 75. 136. 1.

4 A Magyar Literatura Történetei Töredék, Erdélyi Muzéum, 1814, I, 1-10.
} 
zeitungban pedig annak német változata. ${ }^{5}$ A teljes szöveget - a kritikai kiadás igényével - egyetlen alkalommal adták ki: 1916-ban Heinrich Gusztáv rendezte sajtó alá a teljes - általa ismert - magyar szöveget és annak német változatát.

A Tübingai pályamü recepciójának bő kétszáz évét áttekintve megállapítható, hogy a mü befogadástörténete jól elkülöníthető szakaszokra tagolható: az első, jól behatárolható időszak a közvetlenül Kazinczy halálát követő néhány év, bő évtized, amikor még többen éltek olyanok, akik személyesen ismerték a széphalmi mestert, s közvetlenül tőle tudtak a pályamüről. Az őket következő írói generáció azonban vagy nem ismerte ezt a Kazinczy-müvet, vagy kevéssé fontosnak ítélte. Ekkor senki sem akadt, aki említette volna. A század utolsó évtizedében Váczy János kezdte publikálni Kazinczy levelezését. Ö, akár a levelezésben talált adatok alapján, akár más forrásból, mindenesetre már tudott a pályamunka létezéséről. Az ő munkásságához is kapcsolódott Wertheimer Edének az 1808-as országgyüléssel foglalkozó kutatása, amelynek eredményeként Wertheimer föltárta a pályázat kiírásának körülményeit. Ezután jelent meg a mérföldkőnek számító Heinrich-féle szövegkiadás, amelynek eredményeként és hatására az azóta megjelent komolyabb Kazinczyval foglalkozó munkák szerzői ismerik és meg is említik a pályamüvet. A rövid említésen és ismertetésen túl azonban valóban méltatni és az életmü egészében, illetve történeti kontextusában elhelyezni csak a 20. század második felében kezdte a Kazinczy-kutatás.

A még meg sem írt Tübingai pályamü - hasonlóan Kazinczy más, gondos előkészület után született müveihez - már nagyjából a pályázat benyújtása tervének fogantatásától kezdve ismert volt a barátok, a közeli ismerősök előtt. Kazinczy leveleiből értesülve róla végigkövethették a szövegkorpusz formálódását, Kazinczy munkáját, központi gondolatát, az alakuló pályamü egyes részleteit. ${ }^{6}$ Ám hiába folytatott kiterjedt levelezést, ebbe a folyamatba csak egy viszonylag szük szakmai-baráti kört vont be, ami miatt a pályázat sorsának rekonstruálása még bonyolultabb feladat. Közismert a pályamű hányatott sorsa. Kazinczy életében - ahogy említettük - mindössze egy kis részlet, az irodalomtörténeti szöveggyüjtemény látott napvilágot hat évvel később, folyóiratban. Teljes egészében csak a megírása után száznyolc évvel jelent meg, akkor is csak a német szöveg, a magyar alapszöveg kiadása a mai napig csak töredékesen valósult meg.

Ugyanakkor azonban mégis ez az a Kazinczy-mü, amely a legrövidebb idő alatt jutott el a kor nyilvánosságának egyik legfőbb és legfontosabb fórumáig, az

5 Ueber den Wachstum der ungarischen Sprache und Literatur, von den ältesten bis zu den neuesten Zeiten = Wiener Allgemeine Literaturzeitung, 1814, 43.

${ }^{6}$ Említi Berzsenyi Dánielnek, Csehy Józsefnek, Cserey Farkasnak, Dessewffy Józsefnek, Döbrentei Gábornak, Fazekas Istvánnak, Kazinczy Miklósnak, Kis Jánosnak, Kisfaludy Sándornak, Kölcsey Ferencnek, Kultsár Istvánnak, Nagy Gábornak, Pápay Sámuelnek, Prónay Lászlónak, Rumy Károly Györgynek, Szemere Pálnak, Szentgyörgyi Józsefnek, Virág Benedeknek. KazLev V., 429, 439, 442, 453, 464, 467, 470, 488, 490, 509; VI., 1, 9, 11, 25, 30, 35, 37, 62, 82, 83, 87, 92, 96, 114, 146, 152, 168, 179, 181, 188, 202, 215, 231, 304, 324, 340, 379; VII., 200, 470; VIII., 20, 159, 377, 382, 461, 473, 505; IX., 212, 234, 293, 469; X., 168, 209. 
országgyülésig. 1811 decemberében Dessewffy József említette egyik fölszólalásában. Ezután azonban sem hivatalos, sem más nyilvános közegben nem méltatta senki, sőt nagyon hosszú ideig említést sem tettek róla. E hallgatásnak több oka lehetséges: egyfelől mindenekelőtt az, hogy nyomtatásban nem jelent meg, a pályázat lezáratlanul elsüllyedt a bécsi levéltárban; másfelől pedig talán az, hogy Kazinczy és a kortársainak figyelme hamarosan más irányba fordult: elkezdődött a nyelvújítás körüli vita, amely - átmenetileg - minden mást kiszorított az érdeklődés középpontjából. Kazinczy életében még egyszer újra megfigyelhető ugyan a pályamü iránti érdeklődés élénkülése, és ez éppen Dessewffy fölszólalása után, 1812-ben történt: Kazinczy ekkor nagyon szerette volna végre nyomtatásban megjelentetni pályamúvének teljes szövegét, de terve nem sikerült, csak a már említett részletek jelentek meg, így a mü egésze ismételten feledésbe merült.

Kazinczy 1831 augusztusában bekövetkezett halála jó alkalmat kínált a számvetésre. Nekrológok, megemlékezések, méltatások hangzottak el, jelentek meg, de az életmü gazdagsága és a több, párhuzamosan futó, kiemelkedően fontos vállalkozás mellett nem jutott figyelem a tübingeni pályamünek. A méltatók Kazinczy pályaképének fölidézésekor említést sem tesznek róla. Az első nagy, öszszefoglaló munkák a szellemi örökös, Toldy Ferenc nevéhez köthetők. Elsőként A magyar nemzeti irodalom története jelent meg 1851-ben, amelyben még csak a régi irodalmat tekintette át Toldy, ám az 1855-57-es A magyar költészet kézikönyve a mohácsi vésztől a legújabb időkig címü kétkötetes összefoglalásába már belekerült a majdnem kortárs irodalom, így Kazinczy életmúvének vizsgálata is. A második kötet ezzel kezdődik. Mintegy nyolcvan oldalon keresztül tárgyalja a „nagy mester” munkásságát: ennek nagyjából a negyede Toldy szövege, a többi Kazinczyé, szöveggyüjteményszerü bemutatása költészetének és fordításainak. Toldy a Tübingai pályamüvet annyira fontosnak ítélte, hogy kéziratos volta ellenére is megemlítette mint a nyelvújítási viták előtti időszakból való, igen fontos irodalomtörténeti tanulmányt. Közölte a pályamunka címét, hogy németül készült, hogy Kazinczy Prónay László kérésére pályázott, s hogy nem hirdettek eredményt. ${ }^{7}$ Jegyzetben azt is hozzáfüzi, a kézirat Kazinczy Gábornál található, a megírás előzményei között pedig megemlíti Daniel Jenisch híres munkáját, ${ }^{8}$ amelyet Kazinczy a fogsága idején olvasott. Mivel érdeklődése, olvasmányai alapján már ekkor foglalkoztatta Kazinczyt egy magyar nyelvről és irodalomról szóló tanulmány írása, a tübingeni pályázat kapóra jött neki, hogy nézeteit kifejthesse. Toldy szerint a pályatétel kérdése nála „senkit készültebben nem talált.” Figyelemre méltó, hogy Toldy azt is tudta, a pályázatra huszonegy pályamunka

7 Toldy Ferenc, A magyar költészet kézikönyve a mohácsi vésztôl a legújabb időkig, II, Pest, Heckenast Gusztáv, 1857, 19.

8 JENISCH, Daniel, Philosophis-kritische Vergleichung und Würdigung von vierzehn ältern und neuern Sprachen Europens, Berlin, Friedrich Maurer, 1796. Europa tizennégy nyelvei összehasonlitó méltatása. 
érkezett, s hogy - mivel öt évvel később még mindig nem volt eredményhirdetés - a történeti részt Kazinczy megjelentette az Erdélyi Múzeumban. ${ }^{9}$

Toldy szorgalmazta azt is, hogy 1859-ben egy nagyobb ünnepségsorozattal emlékezzenek meg Kazinczy születésének századik évfordulójáról. Ekkor valóban több megemlékezést is rendeztek országszerte; számos emlékbeszéd, méltatás hangzott el vagy jelent meg. Toldy Ferenc is ekkor adott közre Kazinczyról egy terjedelmesebb irodalomtörténeti munkát Kazinczy Ferenc és kora címmel. Toldynak nem ez volt az első Kazinczy-életrajza, hiszen már 1833-ban is írt róla a Magyar Tudós Társaság Évkönyveiben (1833, I.), ám ez az első hosszabb lélegzetvételü munkája csak Kazinczy fogságból való szabadulásáig, vagyis 1801-ig tárgyalta az életét, így abban - természetesen - nem tett említést a Tübingai pályamüről.

Az 1865-ös A magyar nemzeti irodalom története a legrégibb időktöl a jelenkorig címü összefoglalásában azonban már ismételten tárgyalja a pályamunkát. A nagyobb időrendi egységeken belül tematikus csoportokba rendezetten vizsgálja az irodalomtörténetet, az egyik ilyen rész „Az irodalomtörténet újabb stádiuma" címet viseli, s ebben a rövidebb összefoglalásban említi meg Kazinczy munkáját: „Első kísérletei az organikus előadásnak Kazinczy Ferencé, ki egy, mind maig nyomatlan, pályamunkájában (»A m. nyelvnek polgári nyelvvé emelése felöl« 1808) szánt egy rövid fejezetet »A m. literatúra története« futó, de szellemes, átnézetének."10

A kronologikusan következő nagyobb terjedelmü irodalomtörténeti kézikönyvek szerzője, szerkesztöje Beöthy Zsolt (A magyar nemzeti irodalom történeti ismertetése, I-II, Bp., 1877-79; A magyar irodalom története, I-II, Bp., 1893-96; A magyar irodalom kis-tükre, Bp., 1896). Ö már nem ismerhette személyesen Kazinczyt, így - hiába az életmü alapos és részletes ismertetése - az ekkor még csak kéziratos Tübingai pályamüvet nem említi annak ellenére sem, hogy külön fejezetet szentelt Kazinczynak, külön egyet a nyelvújításnak, amelynek bevezetőjében pedig kitért a magyar nyelv elterjedését, használatát segítő pályázatokra (pl. az 1804-es Kulcsár-Prónay pályázatra), törvényekre. ${ }^{11}$

Hasonlóképpen járt el Bodnár Zsigmond is: irodalomtörténetében terjedelmes fejezetet szentelt Kazinczy Ferencnek. ${ }^{12}$ Eredeti, új hangvételü áttekintést írt, sajátosan értelmezte Kazinczy müködését és müveit, sőt bizonyos általa fontosnak tartott életmürészeket - mint például a nyelvújítási vitákat vagy Kazinczy fordításait és verseit - alaposan elemezte, ám a Tübingai pályamüvet ö sem említi, föltehetően ugyanazon okból, mint Beöthy, vagyis valószínúleg ő sem tudott a kéziratban maradt pályamüröl, noha lehetséges, hogy ha hallott is róla Toldytól, a szöveg ismeretének hiányában nem tudott vagy nem akart említést tenni róla összefoglalásában.

Szinnyei József hatalmas lexikonjában (Magyar irók élete és munkái, I-XIV,

9 Toldy 1857 , i. m. 35.

${ }^{10}$ Toldy Ferenc, A magyar nemzeti irodalom története a legrégibb idöktöl a jelenkorig rövid elöadásban, Pest, Emich Gusztáv, 1865, 273.

${ }^{11}$ A magyar irodalom története, szerk. Beöthy Zsolt, II, Bp., Athenaeum, 1896, 181.

${ }_{12}$ Bodnár Zsigmond, A magyar irodalom története, III, Bp., Singer és Wolfner, 1893, 131-152. 
Bp., 1891-1914) részletes és tartalmas összefoglalását olvashatjuk Kazinczy munkásságának. Szinnyei nagyon alapos, az életrajzon túl számba veszi Kazinczynak szinte minden munkáját. Ennél addig nem készült részletesebb leírás, a nagyobb munkái mellett az összes folyóiratcikket is fölsorolja hosszú oldalakon keresztül, valamint - évekre lebontva - itt található a Kazinczyról szóló irodalom legrészletesebb összegyüjtése is. ${ }^{13}$ A Tübingai pályamüvet viszont ő sem említi, annak ellenére, hogy a folyóiratcikkeknél fölsorolja az Erdélyi Múzeumbeli 1814-es irodalomtörténeti rész (A magyar litteratura történetei) megjelenését. A kéziratokról egyébként nem beszél részletesen, annyit említ mindössze, hogy levelei bekerültek az Akadémia levéltárába és kiadásuk folyamatban van.

A Magyar Tudományos Akadémia 1907-ben a következő szöveggel írt ki pályázatot: „Kívántatik Kazinczy Ferenc életrajzának és munkássága beható méltatásának tervezete, néhány kidolgozott fejezet kiséretében. A pályanyertes tervezet szerzője megbizatik az egész munka megírásával. A jutalom, a mely csak az egész munka elkészülte után adatik ki, a Lévay-alap 1907. évi kamataiból 1000 korona. Határnap: 1908. szeptember 30."14 A pályázatra két pályamü érkezett be, az egyik szerzője Váczy János, a másiké Czeizel János volt. Mivel mindkét pályázó többkötetes, nagy ívü munkát ígért, a bírálók nem tudtak dönteni. „Tekintettel arra a rendkívüli körülményre, hogy a kitüzött nyílt pályázatra két nagyterjedelmü, habár be nem fejezett pályamü érkezett, s mind a kettő sok utánajárással, széleskörü forrástanulmány alapján, megfelelő szakértelemmel, alaposan és ritka szorgalommal van kidolgozva, az osztály azt javasolja, hogy mind a kettő 1000-1000 koronás díjjal jutalmaztassék. A nagygyülés az osztály javaslatát elfogadta." 15 Váczy János munkája jelent meg korábban, ez azonban befejezetlen maradt. Váczynak két Kazinczyról szóló monográfiáját is ismerjük, az első 1909-ben jelent meg a Kisfaludy Társaság Költők és Irók címủ sorozatában (Kazinczy születésének 150. évfordulója alkalmából). Ezt a kisebb munkát csatolta is a pályázatához, ezt jutalmazták meg azzal, hogy vállalták a két kötetre tervezett, nagyobb mü kiadását. Ennek első kötete 1915-ben jelent meg, ${ }^{16} \mathrm{Ka}$ zinczy pályáját 1806-ig tárgyalja. A második kötet sajnos nem készült el Váczy 1918-as halála miatt. A megjelent több mint 600 oldalas első kötet, noha nagyon részletes, sajnos a Tübingai pályamü szempontjából irreleváns, mivel Kazinczy munkájának megszületése előtt két évvel zárult. Így tehát csak a jóval rövidebb, hat évvel korábbi munkát vehetjük számításba. Váczy János ebben az összefoglalásban is említi már Kazinczy pályamüvét, noha ekkor nyomtatásban még nem olvasható, csak hét évvel később jelenik meg. Hogy Váczy „felfedezte” a kéziratos pályamunkát, nyilván annak köszönhetö, hogy időközben már régóta folytak a Kazinczy-levelezéskiadás munkálatai. Váczy 1890-ben jelentette meg ennek az

\footnotetext{
13 SzInNYEI József, Magyar irók élete és munkái, V, Bp., Hornyánszky Viktor, 1897, 1261-1291.

14 Akadémiai Értesitö, 1907, 395.

15 Akadémiai Értesitö, 1909, 263.

16 VÁczy János, Kazinczy Ferencz és kora, Bp., MTA, 1915.
} 
első kötetét, majd a kismonográfia megjelenése után két évvel az utolsót. ${ }^{17}$ Így feltételezhető, hogy Váczy - ha máshonnét esetleg nem is - a Kazinczy-levelezésből szerzett tudomást a pályamű létezéséről, valamint arról, hogy Kazinczy ezt mennyire fontos írásának tartotta.

Az 1909-es kisebb munkát Váczy hat részre osztotta. A Tübingai pályamüröl az ötödik fejezetben szólt, Kazinczy eredeti prózai műveinek tárgyalása során. A nyelvújításnak egy egész fejezetet szentelt (ez a negyedik), amelyben részletesen beszél az előzményekről is. Kazinczy fogság előtti müveiből a Bácsmegyeyt ${ }^{18}$ említi, a fogság utániból pedig csupán az 1808-as Marmontel-fordítást ${ }^{19}$ mint a nyelvújítás előzményét. Mindkettő a „szépliteratúrai” nyelvezet megteremtésében játszik szerepet, ebben az időszakban fejlődik, jön létre, alakul ki az igényes, modern prózai nyelvezet, kezdeti regényeink ezeknek egy-egy állomását, esetleg kevésbé vagy jobban sikerült voltát mutatják. Kazinczy számára a nyelvújítás egyik legfőbb indoka éppen az, hogy az irodalom nyelve - és ezáltal a magyar nyelv - gazdag és szabatos legyen. A stílus szépsége az uralkodó eszmény nála, s mivel Váczy János éppen ebből a szempontból elemezte a nyelvújítás előzményeit, ezért nem került bele ebbe a fejezetbe a szintén 1808-as Tübingai pályamü. Viszont nagyon érdekes az a szempont, amely szerint négy prózai múvet egymás mellé rendelt. Váczy azt fejtette ki, hogy az eredeti prózai munkák között négy nagyobb van, amely „írói jelleméhez” adatokat nyújt: három önéletrajz (Pályám emlékezete, Fogságom naplója, Erdélyi levelek) és a tübingeni pályázatra írott kor- és irodalomtörténeti tárgyú munka. ${ }^{20}$ Ezt a négy müvet müfajilag kettéosztja, a Pályám emlékezete és a Fogságom naplója szerinte egymást kiegészítő munkák, szoros értelemben vett önéletrajzok, míg az Erdélyi Levelek és a Tübingai pályamü más természetü írás, ezekben véleménye szerint, elsődlegesen Kazinczy tanítani akarja a nemzetet. Az önéletírások - ha nem is végleges vagy befejezett, de - valamilyen formában Kazinczy életében megjelentek már, és később több kiadásuk is volt, jóval ismertebbek voltak a szélesebb olvasóközönség elött, mint a Tübingai pályamü. Váczy János - a levelek alapos ismeretének köszönhetően - ezt a munkát viszonylag hosszan ismertette, hosszabban, mint az előző hármat együttvéve, feltehetően éppen azért, mivel egy ekkor már/még ismeretlen müvet mutat be és magyaráz.

A Tübingai pályamü tárgyalását a pályázati felhívás történeti ismertetésével kezdte, összefoglalta a pályatétel három kérdését. Kazinczy írását a levelekből vett idézetekkel, szófordulatokkal mutatta be, s nem idézi ugyan pontosan a saját levelezés-kiadását - bár ekkor már megjelent a vonatkozó időszak leveleit tartalmazó kötet -, mégis a jellegzetes szófordulatokból és idézetekből pontosan fölismerhe-

${ }^{17}$ Kazinczy Ferenc levelezése, I-XXI, közzéteszi Váczy János, Bp., MTA, 1890-1911.

18 KazInczy Ferenc, Bácsmegyeynek öszve-szedett levelei, Kassán, Ellinger János Jósef Ts. privil. Könyv-nyomtatónál, 1789.

19 Marmontelnek Szívképzö Regéji. Két könyvben = KAzINCZYnak forditott Egyveleg Írásai, Első kötet, Széphalom, Abaujban, 1808.

20 VÁCZY 1909, i. m. 137. 
tök a levelek. ${ }^{21}$ Inkább a megírás körülményeit és a történeti kontextusát taglalta, s magát a pályamunkát nagyjából fél oldalban összefoglalta. Az már ennyiből is kiderül, hogy ismerhette Kazinczy szövegét, noha a bevezető sorok nem fedik Kazinczy mondanivalóját. Ö ugyanis kizárólag a nyelv és nyelvhasználat szempontjából beszélt, Váczy pedig politikai síkra terelte az értelmezést, amikor azt állította, hogy Kazinczy véleménye szerint „,a hazánk s Ausztria közötti kapcsolat sosem szüntette meg országunk függetlenségét; hazánk különálló volt a multban, az a jelenben is. Ezt uralkodóink is elismerték, tudván, hogy a ki valamely nemzet függetlenségére tör, politikai gyilkosságot követ el. A függetlenség érzése oltja a nemzetbe az erényt, mely ha kihal, örökre vége a nemzetnek."22 Gondolatmenetének második felében Kazinczy azon nézetét foglalta össze, hogy a Magyarországon élő hazafiaknak kötelessége a magyar nyelvet használni a közügyekben; de otthon - természetesen - mindenki olyan nyelvvel él, amilyennel akar. ${ }^{23} \mathrm{Ez}$ a gondolatmenet csak Kazinczy eredeti német szövegében olvasható, a magyar nyelvü rész itt hiányos. Váczy némi lelkesült túlzással azt is állította, hogy Kazinczy pályaírása „erős fajszeretete mellett bizonyít, s hogy volt bátorsága a közérzés kifejezésére, nemzetiségünk megmentéseért égő buzgalmának örökre emlékezetes tanúsága." ${ }^{24}$ Végül azzal zárta a pályaírás történetének elbeszélését, hogy kifejtette, milyen kár, hogy sem akkor, sem azóta nem jelent meg teljes egészében ez a Kazinczy eredeti munkái között olyan fontos kortörténeti munka.

A Váczyé mellett ugyanerre a pályázatra készült másik monográfia - Czeizel János munkája - csak 1930-ban jelent meg, Kazinczy halálának százéves évfordulója alkalmából. ${ }^{25}$ Ez szintén több kötetes monográfiának készült. Az előszóban a szerző leírja, hogy azért döntött könyvének kiadása mellett, mert közeledik a jeles évforduló és Váczy János nem tudta befejezni a saját munkáját, ő pedig azóta megírta a hiányzó két kötetet. ${ }^{26}$ Azonban - nem tudni miért - végül ennek a monográfiának sem jelent meg a második és a harmadik kötete, csak a már jó húsz évvel korábban megírt első. Ez a kötet azonban - akárcsak Váczyé - a rabságból való kiszabadulással ér véget, és nem jut el a Tübingai pályamü megírásának idejéig.

A Tübingai pályamü recepciótörténetének legfontosabb állomása, Heinrich Gusztáv 1916-os szövegkiadása. Heinrich Wertheimer Ede buzdítására már jóval korábban elkezdett foglalkozni a pályamunka kérdésével. 1899 áprilisában a Philologiai Társaság ülésén tartott előadást a pályázatról, ennek egy rövidített változata

${ }^{21}$ KazLev V., 1894, i. m. 431, 446; KazLev VI., 1895, i. m. 30.

22 VÁCZY 1909, i. m. 140.

${ }^{23}$ KaZinCZY 1808/1916, i. m. 68.

${ }^{24}$ VÁCZY 1909, i. m. 140.

${ }^{25}$ Czeizel János, Kazinczy Ferenc élete és müködése. A M. Tud. Akadémiától a Lévay-jutalommal kitüntetett pályamunka, Bp., Kir. Magy. Egyetemi Nyomda, 1930.

${ }^{26}$ Uo., 4. 
megjelent tanulmány formájában is. ${ }^{27} \mathrm{~A}$ szövegkiadást a szakma nagy várakozással fogadta, az 1917-es évben öt recenzió is született róla, Gálos Rezső, ${ }^{28}$ Rácz Lajos, ${ }^{29}$ Simai Ödön, ${ }^{30}$ Szigetvári Iván ${ }^{31}$ és Weber Arthur ${ }^{32}$ tollából. A recenziók közül Rácz Lajosé és Weber Arthuré nem más, mint részletes ismertetés, néhány általuk fontosnak tartott apró kiegészítéssel. Rácz Lajos, aki a sárospataki református teológia tanára volt, a sárospataki kötődést és a történelmi hitelességet helyezte középpontba, ezért kijavította Kazinczy pályamüve néhány történelmi adatának tévedését, miután összefoglalta Heinrich bevezetőjét a pályázat lezajlásáról. Recenziójának végén még külön bekezdést szentelt a Heinrich által közölt Kopitar-bírálatnak. Ennél a résznél érezhetően elveszítette higgadt objektivitását, és kifakadt, hogy ez a „Básta, Karaffa és Bach szellemű censor nem érti, hogy egyes protestáns írók, akik mindig a türelmet hirdetik, hogyan követelhetik a nyelvi egységet, holott ez alapon époly jogosnak lehet mondani a vallási egységre törekvést is, - vagyis Kopitar a magyar protestánsok türelemben részesítéséért megkövetelné, hogy mondjanak le nemzeti nyelvükröl." "33 Végül ismertetését két pataki tanárról szóló megemlékezéssel zárja - mindkettőt Kazinczy említi pályamüvében -, akik még Kazinczy ifjúkorában kitüntek szép magyar előadásaik által. Összefoglalásul leírja, hogy az akadémia és Heinrich Gusztáv nagy és érdemes dolgot cselekedtek azzal, hogy ezt a müvet közzétették.

Weber Arthur recenziója írásakor Budapesten volt gimnáziumi tanár. Hasonló ismertetést írt, azzal a különbséggel, hogy ő a pályamü kultúrtörténeti jelentőségére hívta fel a figyelmet. Írásának nagyobb részében történeti összefoglalást adott a magyar nyelv uralomra jutásának küzdelmeiröl. Fölhívta a figyelmet arra, hogy a magyar nemzeti törekvés a bécsi müvelődési viszonyokból vette az eredetét, bécsi példaadás eredményeképpen alakult. Tárgyalja Gottsched reformjait, majd a 18. századi akadémiai és irodalmi törekvéseket, végül a német állameszméhez és ennek következetes megvalósítójához, II. Józsefhez érkezett gondolatmenetében, majd az erre válaszként megszülető reakcióról szólt, azaz az 1790-es országgyülés nyelvi törekvéseiről, amely valójában elindította a magyar nyelv jogaiért való küzdelmet. Ebbe a folyamatba állította Kazinczy életmüvét és müködését is, amelynek - a nyelvügy szempontjából - egyik csúcspontja a Cottaféle pályakérdés. Az utolsó két bekezdésben először ismertette a pályázat tör-

${ }^{27}$ Heinrich Gusztáv, A tübingai pályakérdés 1808 = Egyetemes Philologiai Közlöny, 1899 , $436-442$.

${ }^{28}$ GÁlos Rezső, Kazinczy Ferencz tübingai pályamüve a magyar nyelvröl = Irodalomtörténeti Közlemények, 1917, 245-248.

${ }^{29}$ Rácz Lajos, Kazinczy Ferenc tübingai pályamüve a magyar nyelvröl = Sárospataki Református Lapok, 1917, 53-54.

30 SimaI Ödön, Kazinczy Ferencz Tübingai pályaírása = Magyar Nyelv, 1917, 220-225, 284-289.

31 SZIGETVÁRI Iván, Kazinczy Ferenc tübingai pályamüve a magyar nyelvröl = Irodalomtörténet, 1917, 417-421.

${ }^{32}$ WeBer Arthur, Heinrich Gusztáv, Kazinczy Ferencz tübingai pályamüve a magyar nyelvröl = Egyetemes Philologiai Közlöny, 1917, 565-566.

${ }^{33}$ RÁCz 1917, i. m. 54. 
ténetét, átvéve ugyan Heinrich egyik hibásan írt névalakját (Fejes Iván, ${ }^{34}$ János helyett), ám nem Heinrich mondanivalóját foglalta össze - csak az adatokat vette át -, hanem saját gondolatmenetét fejtette ki. Emellett dicsérően szól az elvégzett munkáról, a kiadásról, rávilágítva arra, hogy a 19. század eleje kultúrtörténetének, müvelődéstörténetének milyen fontos állomása ez a pályázat. Olyannyira, hogy kilátásba helyezte, hogy a Magyar Történelmi Társulat által majdan megjelenő források között ott kell lenniük a tübingai pályamunkák kiadásának. Nagy kár, hogy ez nem történt meg, mára sajnos a Bécsben őrzött pályamunkák - mint tudjuk - megsemmisültek.

A következő recenzióíró, Gálos Rezső, ebben az időben még temesvári kereskedelmi iskolai tanár volt. Könyvismertetése Kazinczy összes müveinek kiadástörténeti áttekintésével kezdődik, majd Heinrich kiadásának előszava alapján összefoglalta a pályázat körülményeit. Ôt is nagyon érdekelte Kopitar bírálata, külön bekezdést szentelt az ismertetésének. Gálos ezután alapos összevetésnek vetette alá a magyar és a német szöveget, amelyböl figyelemre méltó következtetéseket vont le. Megállapította, hogy eltérés van a két szöveg között. Továbbá azt is, hogy a magyar szöveg a némethez képest töredékes, és nem pusztán azért, mert hiányzik belőle egy nagyobb rész. Néhány kisebb szakasz indokolatlanul hiányzik a magyar szövegből, több helyen emiatt értelmetlenné és logikátlanná válik, viszont olyan eset is akad, amikor bizonyos német szerzők neve a magyar részben szerepelnek, míg a németből kimaradnak. Fölvetette, hogy milyen fontos lenne tudnunk, mennyi vajon Rumy Károly szerepe a pályamüben, aki a német szöveget átjavította. Ez a kérdés a két további recenzió ismeretében válik különösen érdekessé. Gálos szerint az egész szöveg nagyon jellemző Kazinczyra, lendületes a gondolatmenete, a kortársak bírálata, mind-mind felettébb szubjektív, az 1810 körüli Kazinczyra olyannyira jellemző hangvételü. Dicséri Heinrich kiadását, talán csak azt hiányolja, hogy ismertethette volna a beérkezett tanulmányokat és elemezhette volna az egymáshoz viszonyított helyzetüket.

A további két recenzió minősítése nem ilyen pozitív. Szigetvári Ivánnak az Irodalomtörténetbe írott tanulmányára Heinrich egy évvel később válaszolt is. Szigetvári - miután részletesen összefoglalta a történeti eseményeket a pályázat sorsáról és Heinrich kiadásáról - több kifogást is megfogalmazott. Elsőként azt, hogy nincs teljes magyar szöveg, noha Heinrich a Philologiai Közlönyben megjelentetett írásában megígérte, mégsem fordította le a hiányzó részeket. Ö is felhívta a figyelmet a magyar és német szöveg eltéréseire, amiket jelölni, jegyzetelni kellett volna a kiadásban, és figyelmeztetett, ha majd az összes munkák között újra megjelenik, ezt nem szabad elmulasztani. Ezután részletesebben kifejtette Heinrich egyik - szerinte - alapvető tévedését. Nevezetesen azt, hogy Kazinczy pályamunkáját átnézte és javította volna Rumy Károly. Szigetvári, szintén a levelezésből kiindulva, azt állította, hogy Kazinczy Nitsch Dániel sárospataki tanárral akarta átnézetni a pályamüvét, éppen azért, mivel Rumy fizikailag ekkoriban túl messze tartózkodott. Ekkor azonban Kazinczy még nem tudta, hogy Nitsch há-

${ }^{34}$ Weber 1917, i. m. 566. 
rom nappal korábban meghalt. Rumynak a kéziratot Kazinczy csak hónapokkal később küldte el, amikor már a kinyomtatás szándéka miatt kérte föl, hogy javítsa ki német fordításának magyaros hibáit. Szigetvári végkövetkeztetése tehát az, hogy Kazinczy „a pályázatra küldött szöveg átnézésére Nitsch közbejött halála miatt senkit föl nem kért." ${ }^{35}$ Még egy apróbb hibára, elírásra hívta föl a figyelmet: a Heinrich által idézett 1808. július 27-én kelt Kazinczy-levél címzettje nem Prónay László, hanem Cserey Farkas. Végezetül Heinrich bevezetőjének szerkezeti kuszaságát kifogásolta, szerinte ez a gondolati összevisszaság nehézkessé teszi a megértést, valamint az sincs világosan kimondva, hogy az eredményekből mi Wertheimer és mi Heinrich kutatása. Az utolsó néhány sorban megpróbálta a kritika élét némileg csökkenteni azzal a vallomással, hogy ennek a kiváló tudósnak ez a munkája így is értékes gyarapodását jelenti a korszakról való ismereteinknek.

A recenzióra Heinrich Gusztáv 1917. szeptember 16-ai keltezéssel felelt, és ez a következö évi Irodalomtörténet 1-2. összevont számában jelent meg. ${ }^{36}$ Ebben Heinrich megpróbált pontról pontra felelni az őt ért kritikákra. A bevezetőben elmondta, hogy először 1899-ben számolt be Kazinczy pályamüvéről, majd magát a szöveget 1913 végén adta sajtó alá, de a nyomda a háborús helyzet miatt csak 1915 végére készült el vele, így jelent meg 1916-ban. S bár nem szokása ellenbírálatokat írni, most mégis megteszi, mert Szigetvári írásában van három olyan pont, amelyek nagyrészt Kazinczyra vonatkoznak, és ezeket tisztázni kívánja. Elsőként azt, hogy a bíráló szerint nem világos, mi az ő és mi Wertheimer Ede munkája. Felháborodottan kérdezi: „Mi ez? Vád vagy gyanúsítás?” ${ }^{37}$ Wertheimer Ede híres tanulmánya 1896-ban jelent meg. Ebben fejtette ki a pályázat kiírásának körülményeit. ${ }^{38}$ Ám őt csak a dolog politikai része érdekelte, az irodalmi oldallal nem kívánt foglalkozni, és Heinrichet kérte föl, hogy ezt tegye meg. Ezért utazott Bécsbe, ahol a belügyminisztérium levéltárában összegyüjtötte és átnézte a pályázat anyagát. A másik dolog egy félreértés, nevezetesen az, hogy Heinrich ígéretet tett volna a pályamunka teljes magyar fordítására. Ezt ő úgy értette, hogy a Kazinczytól származó magyar szöveget - amelyet akkor még nem ismert fogja közzétenni, arról nem tehet, hogy ez a rész nem teljes. Heinrich a kortárs kutatókat éppúgy bírálta, mint Kazinczy pályamủvét, amikor azt mondta: „Aki nem tud annyit németül, hogy Kazinczy múvét megértse, ne foglalkozzék a nagy reformátorral és korával, mert nem megy semmire. Különben úgy vagyok meggyőződve, hogy Kazinczy nagyon jól tudta, hogy mit tesz, mikor (egyebekben is gyönge) müvének leggyöngébb részét mellőzni akarta a tervezett magyar kiadásban. Hisz nemsokára belátta, hogy pályamüvének akár német, akár magyar kiadását legjobb lesz végleg elejtenie." ${ }^{39}$ Heinrich szerint tehát ez mára csupán

\footnotetext{
35 SzigetváRi 1917, i. m. 421.

${ }^{36}$ HeInRICH Gusztáv, A tübingai pályázathoz = Irodalomtörténet, 1918, 85-86.

37 Uo., 85.

38 Wertheimer Ede, Az 1807. évi magyar országgyülés = Századok, 1896, 394-412.

${ }^{39}$ HeInRICh 1918, i. m. 86.
} 
egy történetileg érdekes politikai röpirat, egészen pontosan mindössze a német része tekinthető annak, ugyanis csak az szerepelt a pályázaton.

Végezetül Heinrich a Rumy Károllyal kapcsolatos fölvetésre válaszolt. Ismételten megerősítette, hogy szerinte Rumy átnézte Kazinczy szövegét és ennek bizonyítására ugyanarra a levélre hivatkozik, amire Szigetvári is - csak éppen pontosan ellenkezö állításának alátámasztásául. Heinrich itt megint elkövetett egy tollhibát, a július 27-ei dátum helyett ugyanis július 2-át írt. Igaz ugyan, hogy Kazinczy mind a két napon írt levelet Cserey Farkasnak, és mind a két levél fontos, Heinrich itt mégis összekeveri a dátumokat. Nézzük végig, hogyan rekonstruálható az eseménytörténet a levelezés alapján: Kazinczy július 2-án arról értesítette Csereyt, hogy egy levelet küldött Tübingenbe, miszerint a következő postakocsival fog a pályamúve elindulni, és mindezt csak azért írja, hogy az esetleges késlekedés miatt ki ne zárják. ${ }^{40}$ Mivel a postaút igencsak hosszú Tübingenig, nem valószínű, hogy Kazinczy megkockáztatta volna, hogy a benyújtási határidő lejárta elött mindössze 3 nappal küldte volna el átnézésre a munkáját. A szintén pályázó Döbrentei Gábor is azt írja Kazinczynak július 3-án, hogy tegnapelött adta postára a saját pályamúvét Segesváron. ${ }^{41}$ Viszont nem tudhatjuk, hogy az ilyen fent említett bejelentkező levéllel mennyi időt nyerhetett magának akkoriban a pályázó. Ha esetleg nyerhet ezzel néhány hetet, akkor még beleférhet a július végi átnézés, vagy hogy akkor küldje csak el a szöveget Tübingenbe. Prónay Lászlótól meg is kérdezi még májusban, hogy a „németre fordított dissertatiót Tübingába melly úton kell kiküldeni? Dilizsenszon e, vagy elég volna Kiliánnak adni Juliusnak utolsó napja előtt, 's Cottának még idejében megküldeni Postán a' Kilián recepisséjét?" ${ }^{42}$ Konkrétan tehát az érdekelte Kazinczyt, hogy - ahogy a mostani pályázatok esetében - a postai bélyegző számít vagy ténylegesen oda kell érnie a dolgozatoknak a határidő lejártáig. Sajnos ebben továbbra is bizonytalanságban maradunk, mert Prónay nem válaszolt erre a május végi levélre, s amikor Kazinczy újból írt neki augusztusban, már arról értesítette, hogy a tübingaiak ítélószéke elött van a munka. Kazinczy a július végi levélben írja, hogy pályaírását befejezte, és holnap (július 28-án) küldi Kassára. Ezek a dátumok azért fontosak, mert a pályázat benyújtási határideje 1808 júliusának vége volt. ${ }^{43}$

Feltételezhetjük tehát, hogy Rumy Károly György ezt a szöveget nem javította át, és ebből a szempontból nem lényeges, hogy július elején készen volt-e már, vagy még dolgozott vele néhány hétig és csak július végén küldte el. Kazinczy nem nevesíti Rumyt, hogy neki küldené el, csak a város, Kassa van említve. Ez akár - inkább - Dessewffy Józsefet is jelenthette, ő keltezte az ebből az időből származó leveleit Kassáról, Rumyról viszont tudjuk, hogy éppen ekkoriban költözködött át Iglóról Szomolnokra (vagy a német nevén, ahogy ők használták, Schmölnitzre). Ez majdnem 40 kilométerre esik Kassától (Igló pedig még mesz-

\footnotetext{
${ }^{40}$ KazLev VI., 1895, i. m. 1.

${ }^{41}$ Uo., 4.

42 KazLev V., 1894, i. m. 467.

${ }^{43}$ KazincZy 1808/1916, i. m. 25.
} 
szebb), nem téveszthető össze Kassával egyik sem. A július végi levélben arról számolt be Kazinczy, hogy ha kinyomtatják, nemcsak egy brosúra lesz, hanem egész kis könyv, éppen a 127. lapot írja tele és még lesz $50 .{ }^{44}$ Mivel itt nem a pályázatról ír, leginkább a kiadásról lehet már szó. Annál is inkább, mivel Kazinczy két héttel később Pápay Sámuelnek azt írta, hogy május 28-a óta dolgozott a pályamüvén (holott Kis Jánosnak már május 8-án elküldi pályaművének előszavát ${ }^{45}$ ), amelyet „osztán nékik németre is lefordítottam.” Nem említett semmilyen átrostálót, csupán a mottót árulta még el neki, hogy Pápay felismerhesse, ha majd az ítélet kihirdettetik a Morgenblattban. A címet külön is megírja, ami azért érdekes, mert hely- és időmegjelöléssel zárul: „Gegend von Tokaj, d. 2. Júl. 1808." 46 Úgy gondolom, ez azt mutatja, hogy Kazinczy július elején elkészült és el is küldte pályamunkáját Tübingenbe. Az viszont ebből nem derült ki, hogy átnézte-e valaki annak német szövegét. Kazinczy augusztus 14-én már azt jelenti Prónaynak, hogy pályaírása a tübingaiak ítélőszéke előtt van, mintegy 200 lapnyi terjedelmü, és jelenleg azon fáradozik, hogy letisztázza magyarul és németül, mivel mindkét nyelven ki akarja adni. ${ }^{47}$

Heinrich Gusztáv ezt úgy értelmezte, hogy Kazinczy belátta, nem érdemes a pályamüvel tovább foglalkoznia, és úgymond „ejtette” a témát. Ennek ellentmond azonban, hogy még 1820 májusában is arról panaszkodik Majláth Jánosnak, milyen rossz, hogy a tübingai pályázatra semmilyen válasz nem adatott, nem hirdettek eredményt. ${ }^{48}$

A német szöveggel kapcsolatosan Heinrich a Tübingai pályamü kiadásának bevezetőjében azt írta, hogy a szöveget két példányból ismeri, és eszerint a két német szöveg „,csak helyesírásilag és itt-ott egy-egy szóban vagy fordulatban különbözik egymástól, de mind a kettő nyelv, stílus és orthographia tekintetében rendkívül kifogásos, föleg a bécsi szöveg." ${ }^{49}$ A szöveg hibáiról szólván azt is hozzátette, hogy ő csöndben kijavította a német változat nyelvtani és helyesírási hibáit. Mindebböl - közvetetten - viszont szintén az következik, hogy Rumy Károly György nem nézte és javította át Kazinczy szövegét, hiszen akkor nem lett volna mit kijavítania Heinrichnek - legalábbis nyelvhelyességi hibákat biztosan nem talált volna benne. Végkövetkeztetésünk tehát, hogy Kazinczy Tübingenbe a saját német fordítását küldte el. Ez a példány került aztán a bécsi levéltárba, ami mára elpusztult. Kazinczy egy fél évvel később elküldhette átnézésre Rumynak, de már a kiadás előkészítése miatt. Így Kis Jánosnak már erről számolt be 1808. december 30-án: „Pályaírásom Rumynál van. Ö tisztongatja-meg a’ német fordí-

\footnotetext{
${ }^{44}$ Uo., 11

45 KazLev V., 1894, i. m. 440.

${ }^{46}$ KazLev VI., 1895, i. m. 27.

47 Uo., 30.

${ }^{48}$ KazLev XVII, 1907, i. m. 152.

49 KAZINCZY 1808/1916, i. m. 32.
} 
tást eredeti bűneiből." ${ }^{50} \mathrm{~A}$ kézirat nagyjából egy hónapig volt Rumynál, csak február 5-én írta Kis Jánosnak, hogy „Rumitól végre megkapám pályaírásomat”. ${ }^{51}$

Hasonló következtetésre jutott a nyelvész Simai Ödön is, aki szintén Heinrich szövegkiadását recenzeálta. Ez a leghosszabb kritika Heinrich munkájáról, szinte önálló tanulmánnyá bővült. Simai írása így két részben jelent meg. Kritikája első felében azt taglalta - alaposan átolvasva a levelezést -, hogy Rumy nem javíthatta ki Kazinczy német szövegét, és így a bécsi példány teljes egészében Kazinczy munkájának tekinthető. Szerinte viszont Rumy igenis javította a pályamunkát, de nem ezt a szöveget, hanem az akadémiai példányt: „Ez a kézirat azonban már az a tisztázat, amelynek készüléséről aug. 14-ikén értesíti Prónayt." 52

Kritikája második részében viszont még érdekesebb dologra hívta föl a figyelmet Simai. Ebben a magyar szöveget vizsgálta, és arra a megállapításra jutott, hogy a töredékes magyar szöveg két része nagyon különbözik egymástól. A magyar szövegből hiányzik a teljes második rész, és a harmadiknak is csak az utolsó, irodalomtörténeti szakasza szerepel az akadémiai kéziratban. Ismert azonban egy másik pályamü-kézirat is, amely a debreceni Papszász-hagyatékból került elö. ${ }^{53}$ Így jelenleg - mivel a bécsi megsemmisült - csak két kéziratát ismerjük Kazinczy művének, az akadémiait és ezt a debrecenit. (Heinrich is két kéziratot ismert: a mára megsemmisült bécsit és az akadémiait.) A hiányzó második rész azonban a debreceni kéziratban sem szerepel, csupán az elsőt és a harmadikat lehet kiegészíteni belöle, tehát mindenképpen nagy lacuna van a két szakasz között. Simai Ödön a szóhasználattól kezdve, a mondatok megalkotásáig, nyelvészeti szempontból vetette össze a két részt és arra a végkövetkeztetésre jutott, hogy a két rész nem egy időben keletkezett. Még két súlyos állítással toldotta meg mindezt: elsőként azzal, hogy Kazinczy a pályamüvét eredetileg nem magyarul írta, és a magyar szöveg csak a német fordítása, másodsorban pedig azt állította, hogy a magyar szöveg második része nem is Kazinczy munkája. Bár Simai mindezt csak az akadémiai kézirat ismeretében tette, érvelése mégis olyannyira figyelemre méltó, hogy érdemes alaposabban is megvizsgálni.

Első állítása nem elég meggyőző. Maga Kazinczy állította ugyanis az ellenkezőjét Kis János véleményének: „Én a' magam Irásomat magyarúl dolgozom, aztán lefordítom németre, 's által adom valamelly Graeculusnak, hogy revideálja, corrigálja, 's alkalmaztassa a' német ízléshez." ${ }^{54}$ Kazinczy szándéka tehát magyarul megírni a munkát, és nincs is okunk ebben kételkedni. Egyrészt azért, mivel a bécsi szövegen jól látszik, hogy noha Kazinczy jól tudott németül, természetesen magyarul jóval könnyedebben - és nyelvtanilag helyesen - fogalmazott.

${ }^{50}$ KazLev VI, 1895, i. m. 171.

51 KazLev VI, 1895, i. m. 215.

52 Simai 1917, i. m. 224.

53 A kéziratról lásd AJKAY Alinka, „Pályaírásomnak egész ideája, igen is, csak a’ nationalismus. Az nekem az idolumom, nem holmi apró tekintetek. "Kazinczy Ferenc Tübingai pályamüvéröl=Irodalomtörténeti Közlemények, 2007, 520-537.

${ }^{54}$ KazLev V., 1894, i. m. 441. 
Simait megzavarhatta az a tény, hogy a pályamünek csak a német szövegét találta teljes egészében, a magyar ennek csak a fordítása. Ráadásul töredékes is. Ez azonban csak az akadémiai példányra nézve érvényes. A teljes pályamünek, azaz a magyar és a német szövegnek több másolata is létezett: az egyikről Kazinczy maga számol be Kis Jánosnak 1809. február 5-én, miután visszakapta pályaírását Rumy Károly Györgytől, aki ekkorra tudta elkészíteni a javítást. Kis János még decemberben kérte Kazinczy szövegét, illetve „egy rövid rajzolatot a’ M. Literaturának mostani állapotjáról. Ez néked másszor is könnyü volna, most pedig annál könnyebb, minthogy tsak pályaírásod utolsó szakaszát kell rövid summába foglalnod." ${ }^{55}$ Kis egy tervezett, induló negyedéves folyóirat számára kérte az írást, amelynek az első számát még januárban el kell küldenie Pestre, tehát január közepéig szeretné megkapni Kazinczy szövegét. Erre csak február elején tudott válaszolni Kazinczy: „Rumitól végre megkapám pályaírásomat, 's az vala első dolgom, hogy az általad kívánt czikkelyt néked megküldhessem. Elmaradván valahol Bécsi útam alatt a' Pályaírás' magyar textusa, ezt a' németből mingyárt ezen papirosra fordítám; e' miatt van ebben olly sok igazítás." ${ }^{56}$ Végül azonban a folyóiratterv nem valósult meg, számunkra azonban ez a levélrészlet igazolhatja a több - akár több autográf - kézirat létezésének feltételezését.

Heinrich Gusztáv két kéziratot ismert, a bécsit és az akadémiait. Ma is két kézirat ismeretes, az akadémiai és a debreceni. A jelenleg ismert kéziratok egymással bonyolult összefüggésben állnak, ezek megvilágítását szolgálja az alábbi táblázat:

\begin{tabular}{|l|l|l|}
\hline Bécsi kézirat - német nyelvü & $\begin{array}{l}\text { Akadémiai kézirat } \\
\text { - magyar és német nyelvü, } \\
\text { itt csak a magyar nyelvü részt } \\
\text { tekintem át, mivel } \\
\text { a német szöveg teljes }\end{array}$ & $\begin{array}{l}\text { Debreceni kézirat } \\
- \text { magyar nyelvü }\end{array}$ \\
\hline $\begin{array}{l}\text { 1. rész: hiányzik a német } \\
\text { szövegben meglévő } \\
\text { utolsó négy lap (Heinrich } \\
\text { ismert, mára megsemmisült } \\
\text { az eredeti }\end{array}$ & $\begin{array}{l}\text { Megjegyzendő azonban, } \\
\text { hogy ebben a kiadásban } \\
\text { a német és a magyar szöveg } \\
\text { betümérete eltérö, a német } \\
\text { nagyobb betükkel van szedve.) }\end{array}$ & $\begin{array}{l}\text { 1. rész: az utolsó bekezdés } \\
\text { hín teljes szöveg }\end{array}$ \\
\hline $\begin{array}{l}\text { 2. rész: Heinrich kiadásából } \\
\text { ismert, mára megsemmisült } \\
\text { az eredeti }\end{array}$ & $\begin{array}{l}\text { 2. rész: hiányzik } \\
\text { 2. rész: hiányzik }\end{array}$ \\
\hline
\end{tabular}

${ }^{55}$ KazLev VI., 1895, i. m. 150.

${ }^{56}$ Uo., 215. 


\begin{tabular}{|c|c|c|}
\hline $\begin{array}{l}\text { 3. rész: Heinrich kiadásából } \\
\text { ismert, mára megsemmisült } \\
\text { az eredeti }\end{array}$ & $\begin{array}{l}\text { 3. rész: hiányzik a német } \\
\text { szöveg első tizennégy lapja }\end{array}$ & $\begin{array}{l}\text { 3. rész: hiányzik a német } \\
\text { szöveg első négy és fél lapja, } \\
\text { majd nyolc lap után nagyobb } \\
\text { (hét és fél lapnyi) hiátus } \\
\text { következik, amely után már } \\
\text { csak töredékesen kapcsolódik } \\
\text { vissza a szövegbe mintegy } \\
\text { négy kéziratos lap }\end{array}$ \\
\hline
\end{tabular}

A debreceni kéziratról - összeolvasva az akadémiai kézirat magyar szövegével, amelyet Heinrich kiadott - elmondható, hogy ez a korábbi verziója Kazinczy pályaművének. A kéziratról először hírt adó Pósa Ágnes tanulmányában meggyőző érvekkel támasztotta alá a szöveg keletkezési dátumát, eszerint 1808 májusában vagy júniusának elején írhatta Kazinczy. ${ }^{57}$ Pósa azonban nem foglalkozott a Tübingai pályamü keletkezésének körülményeivel vagy a szöveg elemzésével. Megelégedett azzal, hogy a kéziratot beillesztette a Kazinczy-életműbe. Pedig ez a változat szép, tisztázott szöveg, legalábbis az első része. Erről azonban tudjuk, hogy már május elején készen volt. Később azonban fokozatosan szaporodnak benne az áthúzások, a javítások, az utolsó része pedig töredékes. A javításokat vizsgálva egyértelmü, hogy egy részük Kazinczytól, egy másik részük pedig más kezétől származik. ${ }^{58}$ Ezek a javítások azért is érdekesek, mert az akadémiai kéziratból kiadott Heinrich-féle szövegbe már ez a - más által - javított verzió került. Ahol ebben a szövegben javítás van, az akadémiai kéziratban is át van javítva a szöveg, de nem minden esetben ugyanúgy, néhol kissé eltérő szavakkal. ${ }^{59}$ Olyan eset is előfordul, amikor a debreceni kéziratban nincs javítás, az akadémiai mégis bővebb, pontosabb magyarázatot ad ${ }^{60}$ Természetesen olyasmire is akad példa, hogy a debreceni kéziratban nincs javítás, de az akadémiaiban némileg mégis eltérő szöveget találunk. ${ }^{61}$ Érdekes például, hogy amikor az uralkodókról esik szó, a javításba minden esetben egy kevésbé kedvező szófordulat került, például amikor Mária Terézia mint II. József édesanyja uralkodásáról szólt, az „áldott

${ }^{57}$ Pósa Ágnes, Kazinczy tübingiai [!] pályamüvének autográf kézirata a Papszász-hagyatékban = A debreceni Déri Múzeum évkönyve 1977, Debrecen, 1978, 503-506.

${ }_{58}$ Például a 18. (vagy 9. verso), vagy a 23. (12 recto), vagy a 29. (15 recto) stb. oldalon lévő javítás.

59 Például a 22. (11 verso) oldalon a margón más kézzel írva ez olvasható: „egynehány Vármegyét kivévén”, míg a Heinrich-kiadásban: „némely nem nagy számu vármegyét kivévén”. KAZINCZY 1808/1916, i. m. 131.

${ }^{60}$ Például a 21. (11 recto) oldal első jegyzetében itt mindössze annyi szerepel, hogy „Tulajdon szavai.” A Heinrich-félében pontosítva: „Tulajdon szavai Szirmay Tamás Antalhoz és Kazinczy Andráshoz 1779.” KaZINCZY 1808/1916, i. m. 130.

${ }^{61}$ Például az 55. (28 recto) oldalon olvashatjuk: „Van, a’ ki így kél a deák nyelv’ ügyének védelmére”; ugyanez a Heinrich-féle kiadásban: „Eggyike azoknak kik ellenünk költek-ki, így okoskodik". KAZINCZY 1808/1916, i. m. 145. 
emlékezetủ anyja" át van húzva és fölé írva: ,anyjának uralkodása”. ${ }^{62}$ Vagy II. Józseffel kapcsolatosan szintén át van húzva a „népek’ boldogságára élt Császártól” kifejezés, helyette fölé írták egyszerüen, hogy „Józseftől”. ${ }^{63}$

A kézirat folyamatos szövege - kisebb javításokkal - egészen a 70 . (34 verso) oldalig tart, innentől kezdve megszünik az oldalszámozás. A 64 . (32 verso) oldaltól már olyan rész következik, amely hiányzik Heinrich kiadásából; ez a pályamü első részének utolsó harmada. A második rész teljes egészében hiányzik ebből a kéziratból is. A meglévő kézirat a - Heinrich-féle kiadásban is hiányos - harmadik részben csatlakozik majd vissza a szöveghez. Méghozzá olyan résszel, amely hiányzik Heinrichéből, ám ez a debreceni kézirat is töredékes, a szövegkiadás lapszámozása szerint a 154. oldalon ér véget. (Sajnos a leírást bonyolítja, hogy kénytelenek vagyunk a Heinrich-féle kiadás oldalszámaira hivatkozni, mivel más nem áll rendelkezésünkre, ennél a résznél már a kéziratos lapszámozás is megszünik.)

Simai Ödön állítása szerint a 154. oldaltól a Heinrich által kiadott munka a szöveg végéig (177. oldal) nem Kazinczy müve, és csak 1815 után kerülhetett papírra. Simai ezzel nem kevesebbet állított, mint azt, hogy az innentől (154. oldal) kezdődő több mint húsz oldalt más szerző fordította volna le később a német szövegből. A Tübingai pályamü harmadik részének magyar szövege Heinrich kiadásában a 148. oldalon kezdődik, Simai Ödön szerint ez a rész (154-ig) még Kazinczyé. Ennek a szövege még megegyezik az Erdélyi Múzeumban közölt szöveggel, innen kezdődően azonban lényegesen fiatalabb szókincset mutat. Ezt a részt a német szöveggel összevetve láthatjuk, hogy nem is a pontos fordítása annak, hiszen bizonyos részek hiányoznak, másokat pedig betoldott az író. ${ }^{64}$ Valóban, az 59. jegyzetben említett példákból már látszik az a fontos tény, hogy 1815 után keletkezett kifejezéseket tartalmaz. A Zrinyiász és a hösköltemény szavakról Simai korábban írt tanulmányaiban bizonyította már, hogy csak az Erdélyi Múzeum 1815-ös II. füzetében jelentek meg, az első valószínúleg Kazinczy találmánya, míg a második Döbrenteié. ${ }^{65}$

Több olyan, jellemzően ebben a részben használt szó is van, ami gyanakvásra adhat okot, hogy későbbi szövegpótlásról lehet szó. Simai elsőként a költészet szóra hívta föl a figyelmet. ${ }^{66}$ Azt állította, hogy ez a szó a nyelvújítás „későbbi

${ }^{62}$ A 29. (15 recto) oldalon.

${ }^{63}$ A 30. (15 verso) oldalon.

${ }^{64}$ Hiányzik például a németből: „többek között, Zrinyi Miklós Zrinyiászát hexameterekben kezdé dolgozni, mielőtt Birisi, primás Barkóczynak e versnemben éneklé alkalmi dalát, s Kalmár izetlen kötetkéjével (Prodomus, Pozsony, 1770) föllépe.” Itt Ráday Gedeonról beszél, az ez előtti és ez utáni mondatok megvannak a németben, ez a betoldás hiányzik. KAZINCZY 1808/1916, i. m. 111, 161; vagy Kis Jánosról szólva: „Mit Zrinyi-verselésnek nevezhetnők, mert Zrinyi így adá hős költeményét s más kisebb dalait.” Kazinczy 1808/1916, i. m. 122, 174.

${ }^{65}$ SIMAI Ödön, A Zrinyiász neve = Irodalomtörténet, 1914, 252-253; SIMAI Ödön, Hösköltemény = Magyar Nyelv, 1914, 275-276.

${ }^{66}$ A szövegben többször is előfordul KAZINCZY 1808/1916, i. m. 161, 162, 175. 
szülöttje"; a NyÚSz.-ra hivatkozik. Ebben az első előfordulásra tényleg az 1833as évet találjuk. Az első megjelenését a TESz. is csak 1830-ból ismeri, és a dolog külön érdekessége az, hogy éppen erre a Simai-cikkre hivatkozik. ${ }^{67}$ Mindenképpen fontos felfigyelni arra, hogy a 154. oldal elött Kazinczy szisztematikusan poézist használt a költészet szó helyett. ${ }^{68} \mathrm{~A}$ költészet szó elöfordulása - jelenlegi tudásunk szerint - 1830 tájékára, azaz nagyjából erre az időszakra vagy Kazinczy halála (1831) utánra tehető. Megpróbáltam magam is a nyomára bukkanni a szó használatának Kazinczy mủveiben, de nem fordul elő egyszer sem. Elmondható, hogy Kazinczy egész életében a poézist használta, méghozzá meglehetősen sürün, hiszen számos munkájában értekezett a költészetről. Simai Ödön még hoszszan fejtegette, hogy kinek mely müvében fordult elö a kifejezés először, mivel azonban ennek az egy szónak az alapján nem lehetséges pontos teóriát fölállítani, további szavakat is bevont a vizsgálódásába. Ilyenek például a rag, a vállalat, a modor, a hírlap, a nyelvtan, a szinház, a latin, a müveltség, amelyek azelött még újságlevél, grammatika, deák, cultura stb. szóhasználatban léteztek, Kazinczy korábban nem használta ezeket a szavakat a magyar szövegben. A magyarított szavak esetében különös, hogy addig következetesen mindig a deák nyelvröl beszélt például Kazinczy, vajon miért váltott volna át a pályamü végén a latinra? A korábban nem szereplő szavakat (rag, vállalat, modor, hírlap, nyelvtan, színház stb.) Simai részletesen végigelemezte, megvizsgálta, kinek az alkotása és mikor jelent meg először. Végeredményben: van ugyan közötte olyan, amely Kazinczy életében már létrejött (pl. a modor-nak a legkorábbi előfordulása 1825-ös), de az itt felsorolt szavak többsége az 1830-as évek első felében, Kazinczy halála után keletkezett. Ellenőrizve Kazinczy müveit, valóban, egyikben sem fordultak elö egyetlen egyszer sem ezek a szavak. Így egyelöre megválaszolatlan a kérdés, hogyan és ki által kerültek bele akkor Kazinczy autográfnak vélt kéziratába?

Simai részletesen leírta, miként haladt a „nyomozása”, és milyen megfigyeléseket tett az akadémiai kézirattal kapcsolatosan. A bilingvis kéziratról ténylegesen megállapítható, hogy az első része szépen tisztázva másolt, gondos írás, míg a kézirat vége felé a tinta színe is elüt és az íráskép is sietősebb, javításokkal tüzdelt, elnagyoltabb írás. Mégsem jelenthetjük ki azonban egyértelmủen, hogy más kéz írása, mégha lehetséges is. Simai Ödön szerint egyértelműen másé, de olyasvalakié, akinek a kézírása nagyon hasonlít Kazinczyéra. Ennek az előfeltevésnek a mentén kezdett el vizsgálódni és hasonlította össze sorra azoknak a kézírását a szöveggel, akik szóba jöhettek mint a kéziratba belejavítók. Simai leírta, hogy a kézirat Kazinczy Gábortól került az Akadémiára, ám az ő írása teljesen elüt nagybátyjáétól. Bajzának és Toldynak - akik kiadták Kazinczy műveit - is egészen más az írása, szintúgy Helmeczynek. Szemere Pál írásképének vizsgálatánál viszont megtalálta a feltételezett hasonlóságot. Nem kevesebbet állított tehát, mint azt, hogy az ominózus ,részletet Szemere írta bele a Tübingai pályaírás

${ }^{67}$ A magyar nyelv történeti-etimológiai szótára, II, főszerk. Benkő Loránd, Bp., Akadémiai, 1970, 607.

68 Uo., 153. 
kéziratába, sőt az új szók hangos szószóllása szerint az ő fogalmazásának is tekintendő. A kiadás 155. lapjától kezdve tehát végig a költeményeket, melyek még Kazinczy másolásai a kéziratban, magyarázó szöveg Szemere Pál munkája.”69 Kazinczy és Szemere kézírásának hasonlóságára idézi Kazinczy 1831-es levelét, amelyet Kis Jánosnak írt Pécelről, ahol hosszan vendégeskedett Szemerééknél: „Ma egy hete tehát kijöttem Pestről az én Szemerémmel, mind hogy kiélhessem vele magamat, mind hogy itt dolgozhassam. De a' hol az ember olly sokat hallhat 's láthat, mint én ezen második magamtól - (Szemerének gondolkozása, charactere, ízlése annyira enyém, hogy én magamhoz hasonlóbbat senkit sem ismertem miolta élek - rendes, hogy kézírásaink is annyira hasonlítanak, hogy sok ízben nem tudtam már, én írtam e, vagy Szemere) - ott nem lehet dolgozni." 70

Simai magyarázata szerint Szemere még a Muzárion számára kapta meg a kéziratot 1831-ben, amelyet Kazinczy halála után kiegészített. ${ }^{71}$ A recenzió záró részében Simai kifejti, hogy Heinrich kiadása sajnálatos módon filológiailag sem jó, a kéziratot látva nem érti az átírás következetlenségeit és önkényességét, például hogy nem örizte betühíven a hosszú és rövid magánhangzókat, vagy hogy számos esetben betüket is megváltoztatott.

Kazinczy 1831. augusztus 22-én bekövetkezett halála után szinte azonnal megindult a szervezkedés, hogy a mủveit ki adhatja ki, hová kerüljenek a kéziratok, és hogy az egész irodalmi hagyaték kinek a kezébe kerüljön. Mindez a Kölcsey-levelezésből rekonstruálható. A hónapok óta tartó felföldi kolerajárvány miatt Kazinczyék és Kölcseyék is elzárva voltak a külvilágtól, csak a barátok aggódó és a különböző kedves ismerősök halálhíréről beszámoló levelei érkeztek sorban.

Kazinczy halálhírét Bártfay adta hírül Kölcseynek augusztus 31-én. ${ }^{72}$ Innentől hosszú hónapokon, sőt éveken keresztül a Kölcsey-levelezésben sűrün előforduló téma volt a Kazinczy-hagyaték ${ }^{73}$ (én két éven keresztül, a Muzárion 1833-as megjelenéséig követtem a nyomát). Az ekkor már müködő Tudós Társaság Kölcseyt kérte fel a Kazinczy fölött tartandó emlékbeszéd elmondására, emiatt Kölcsey biográfiai adatokat kért barátaitól, az Akadémia pedig szerette volna az özvegytől megszerezni a Kazinczy-hagyatékot és a kiadás jogát, hogy - mint Kisfaludy

${ }^{69}$ Simai 1917, i. m. 288.

${ }^{70}$ KazLev XXI, 1911, i. m. 502.

${ }^{71}$ Ez ugyan némileg ellentmond annak a korábbi állításának, miszerint Kazinczy Gábortól került volna a kézirat az Akadémiára. Kazinczy Gábor nagybátyja halálakor mindössze 14 éves volt, kéziratokat Széphalomról csak 1837-ben vitt magával. Lásd GergYe László, Kazinczy Ferenc kéziratos hagyatéka, Bp., MTA, 1993 (Az MTAK kézirattárának katalógusai, 21), 15.

${ }^{72}$ KFMM Levelezés II., i. m. 380.

73 Uo., 384 (Bártfay Kölcseyhez, 1831. szept. 8.), 386 (Kölcsey Bártfayhoz, 1831. szept. 20.), 395-6 (Bártfay Kölcseyhez, 1831. szept. 29.), 406-7 (Kölcsey Bártfayhoz, 1831. okt. 21.), 412-4 (Bajza Kölcseyhez, 1831. okt. 26.), 419 (Szemere Kölcseyhez, 1831. nov. 7.), 421-2 (Bártfay Kölcseyhez, 1831. nov. 9.); KFMM Levelezés III., 11 (Döbrentei Kölcseyhez, 1832. jan. 25.), 20 (Döbrentei Kölcseyhez, 1832. febr. 20.), 28-9 (Döbrentei Kölcseyhez, 1832. ápr. 10.), 31 (Bártfay Kölcseyhez, 1832. ápr. 11.), 36 (Bajza Kölcseyhez, 1832. ápr. 20.). 
Károly esetében, akinek a müvei sajtó alá rendezésén folyamatosan dolgoztak egy életmü-kiadásban jelentethessék meg az összes müveket. Az Akadémiához kapcsolódó személyek és törekvések mellett azonban mások is igényt formáltak egyes Kazinczy-munkák és kéziratok kiadására. A levelezést például Guzmics Izidor szerette volna kiadni, Dessewffy József pedig azt tanácsolta az özvegynek, hogy semmit ne adjon oda senkinek, csakis neki. Végül a kéziratok katalógusát Bajza, Szemere és Toldy kapták meg rendszerezésre. Mivel Szemere ekkoriban betegeskedett, Bajza és Toldy végezte el a munkát, javaslatukra pedig az akadémiai tagok támogatták Kazinczy összes munkáinak kiadását, mely 1836-ban kezdődött meg a versek kötetével. ${ }^{74}$ Kölcsey emlékbeszéde az 1832. szeptember 8-án tartott ülésen hangzott el. A beszéd megjelentetéséből a Tudós Társaság körében kisebb botrány tört ki, többen megsértődtek, Szemere ugyanis 1833. február 5-én írta Kölcseynek, hogy megkapta rá az imprimaturt, ${ }^{75}$ május 13 -án pedig azt, hogy a Muzárion ma hagyta el a sajtót, és ebbe beletette Kölcsey emlékbeszédét is, ${ }^{76}$ attól félvén, hogy Döbrentei a Tudományos Gyüjteményben nem adná ki teljes egészében. ${ }^{77}$ Ebből lett végül a sértődés. Nevezetesen abból, hogy Kölcseyt a Tudós Társaság kérte fel, elöttük is mondta el a beszédét. Az ő felkérésükre született beszéd azonban mégsem a Társaság lapjában jelent meg, hanem a Muzárionban. Szemere emiatt hosszas magyarázkodásra kényszerült.

A Muzárion-kötetet végiglapozva igen figyelemre méltó észrevételt tehetünk. A harmadik és a negyedik kötet egyben jelent meg, 1829-től 1832-ig vannak benne írások, főként Szemerétől és Kölcseytől. Azonban bőven megtalálhatók benne még Kazinczy munkái is, többek között a XXIII. rész kereken tíz Kazinczy-verset tartalmaz (320-331). De 1831 júliusából is vannak itt írások például, tehát éppen abból az időszakból, amikor Kazinczy Szemerééknél időzött, és közösen írtak különböző nyelvészeti munkákat, miközben átnézték a régi pályázatokra ${ }^{78}$ készült szóalkotásokat.

A Muzárionban megjelenő Kazinczy által húsz évvel korábban kitalált magyarítások szövegei is köthetök valamiképpen a Tübingai pályamühöz. Amikor például az anima és a spiritus szavakról, illetve ezek fordításáról értekezett Kazinczy, kiderül, hogy a Muzárionban közölt gondolatmenet ${ }^{79}$ már - kicsit egysze-

${ }^{74}$ Kazinczy Ferenc Eredeti munkái, I., összeszedték Bajza és Schedel, Budán, A Magyar Kir. Egyetem betüivel, 1836 .

${ }^{75}$ KFMM Levelezés III, i. m. 147.

76 KöLCSEy Ferenc, Kazinczy = Muzárion, 1833, 376-389.

77 KFMM Levelezés III, i. m. 268.

${ }^{78}$ Balla Antal és Puky Ferenc még 1810-ben írt ki pályázatot a Hazai Tudósításokban, hogy a spiritus, universaliter és az universum szavaknak keressenek magyar megfelelőt. Erre a pályázatra írt - Szemere hatására - Kazinczy is megoldásokat, amivel azonban nem nyert, a pályázati szövege viszont Szemerénél maradt, ezeket nézték át 31 nyarán és ezek jelentek meg az 1833-as Muzárionban (243-267). KazLev VIII, 1898, 464-465.

79 „A' s z e 11 e t' gyökere s z é 1 (a hogy $\alpha v \varepsilon \mu o \varsigma$ szél mennyböl az animus leve) - 's ennek talán a' s z e 1 e k (scindo); minthogy a' s z é 1 az orczabört szeli. A' s z é 1 mondom - ventus, spiritus, anima; az utolsót azon értelemben vévén, mellyben Cicero veszi, midőn a’ rothadt lehelletü 
rübb formában - készen volt a két évvel korábban megírt Tübingai pályamüben. ${ }^{80}$ Ezek az apró tények is igazolni látszanak tehát a Simai-féle felvetést. Nyilvánvaló, hogy Szemerét foglalkoztatta Kazinczy Tübingai pályamüve, és szövegszerüen a fejében járhatott Kazinczy dolgozata éppen ebben az időben, azaz 1831 júliusa és 1833 áprilisa között. Április 16-án ugyanis azt mesélte Kölcseynek, hogy a korábbi levelében küldött hexameterek közül (Kölcsey hat verset küldött azzal a felszólítással, hogy Szemere válasszon belőle hármat) a Szemere által elsőként kiválasztott („Önérzés te vagy a' diadalmas bére nem a' díj”) emlékezteti őt a „Stolz will ich den Spanier”-re ${ }^{81}$ És pontosan ez a mondat volt Kazinczy pályamüvének a jeligéje is, Schiller Don Carlosából (III. felv. 10. jelenet).

A Tübingai pályamü kéziratainak és kritikai sajtó alá rendezésének lényegi problémájára hívta föl tehát a figyelmet Simai Ödön, s érveivel feltétlenül foglalkozni kell érdemben, hiszen Simai észrevételeit mindeddig nem vette figyelembe a szakirodalom.

A Kazinczy-recepcióban halálának 1931-es centenáriuma tekinthető újabb eseménynek. 1931 októberében az Akadémián emlékülést tartottak, az elnöki megnyitó beszédet Berzeviczy Albert mondta. Ez a beszéd ${ }^{82}$ a Budapesti Szemlében Horváth János hosszabb tanulmányával ${ }^{83}$ együtt jelent meg. Szép, nagy ívü, méltató mondatok. Különösen Horváth János tanulmánya fontos, aki súlyozta, kritikusan értékelte, majd mérlegelve elhelyezte Kazinczy munkásságát irodalomtörténetünkben. A Tübingai pályamüről azonban nem beszélt. Négyesy László

Apronius felől azt mondja, hogy nem csak lelke, hanem még lehellete is záp volt. Ne animum eum quidem integrum, sed ne animam quidem puram conservare potuit. In Verrem. 5:58. A' s z é l-böl lesz s z e 1 e 1 n i (spirare), 's innen s z e l e lé s (spiratio); mellyel egy a' s z e 11 e t (spiritus) azon különbséggel, hogy amaz az actiót, ez pedig az actio által producált dolgot teszi; holott némelly ás és és-ben kimenő szavaink, mint péld. o. az írás (scriptio és scriptura) mind a' kettőt jelenti. [...] A' chemiában annál inkább használható, mivel rövid, és így összeforradást épen úgy szenved mint németben: Weingeist b o r s z e 11 e t. [...] A' szellet-nek egy hibája vagyon - hogy végzete ET. Az utóbbik szent helyben láttuk, hogy a' spiritus vester s z e 11 e T E - T E k által tétetett ki, mellyben a' két TE syllaba' hangzása fáj a' fülnek. Változtassuk a' szelletet s z e 11 e mmé, mint a' hogyan a' kell-ből lön k e 11 e m; 's a' szellemetek nem fogja bántani a' fület, 's a' poeta a' keleti szelletet (spiritus vagy ventus orientalis) keleti szellemnek mondhatja." Muzárion, 1833, 252-253.

${ }^{80}$ „Igen is, nálunk lélek mind az anima mind a’ spiritus. De a’ XVdik század' Irójinak munkájiban felleljük a' spiritus ideájára a' szelletet, 's Philosophusaink élni fognak az igen jó szóval, mihelytt reája szükségek lészen, (még pedig, hogy a' szó ens per se subsistens-t és ne productum-ot fessen), azt, a' kellek-ből eredő kellem' (Anmuth) hasonlatossága szerént, szellem-mé változtatván, mert a' szellet annyi mint a' szellés; - noha illyen verbumból eredő substantívum a' spiritus és $\pi v \varepsilon v \mu \alpha$ is. 'S ekkor osztán a' Chemicus borszellemnek fogja nevezhetni az égett-bort, 's a' Montesquieu' fordítója Törvények'szellemének az ö halhatatlan munkája' czímjét." Ez a részlet csak a debreceni kéziratban maradt fenn magyarul, a szövegrészletet lásd AJKAY 2007, i. m. 534-535.

${ }^{81}$ KFMM Levelezés III, i. m. 242.

82 Berzeviczy Albert, Kazinczyról = Budapesti Szemle, 1931/648, 161-166.

${ }^{83}$ Horváth János, Kazinczy emlékezete = Budapesti Szemle, 1931/648, 166-190. 
tanító célzatú monográfiája ${ }^{84}$ szintén az emlékév termése. A magyar nyelv védelme címü fejezetet ${ }^{85}$ teljes egészében a Tübingai pályamü vizsgálatának szentelte. A müvön erősen érezhető Wertheimer Ede történeti tanulmányainak és Heinrich Gusztáv szövegkiadásának hatása a kortárs tudósokra, Négyesy - amint ezt a külön fejezete is illusztrálja - lényeges munkának tartja Kazinczy életmüvében ezt a pályaművet, nem kevésbé lényegesnek mint kortörténeti dokumentumot. Ismertette a pályázat kiírásának körülményeit, összefoglalta a pályamü tartalmát, majd a pályázat további sorsáról is beszélt. A szöveg értelmezéséhez új dolgot nem tett hozzá, és látnivalón nem ismerte a Heinrich-kiadás recenzióit. Lényegesebb viszont, hogy a tanuló ifjúság figyelmét ráirányította Kazinczynak erre az írására, és szélesebb körben ismertté tette. Négyesy kiemelten fontosnak tartotta Kazinczy pályaművét, ez azért feltűnő, mert az egyes fejezetekben nem egy-egy müvet, hanem egy-egy témakört tárgyalt. Amellett, hogy tudós értekezést olvasunk, lírai módon ragadta meg Kazinczy tevékenységének lényegét: „Pályáját véres verítékkel öntözte. Hitt, küzdött, szenvedett és alkotott. Emléke olyan tiszteletet érdemel a haza és az emberiség előtt, mint az egyházban a szenteké." ${ }^{86}$

A következő évben, 1932-ben jelent meg Pintér Jenő nagy irodalomtörténeti összefoglalásának Kazinczyt is tárgyaló kötete. ${ }^{87}$ Ennek a mérhetetlen menynyiségü adatot tartalmazó rendszerezésnek az a furcsasága, hogy Heinrich pályamü-kiadását egyáltalán nem ismerte, miközben Heinrichnek a Bácsmegyeyszövegkiadását igen. Ez azért is különös, mivel Pintér Jenő ismerte és beledolgozta munkájába a legújabb (1931-es) szakirodalmat is. A Tübingai pályamü sorsáról mégis több mint egy oldalon keresztül írt az életrajzi részben ${ }^{88}$ majd még egyszer megemlítette a prózai munkák tárgyalásánál is ${ }^{89} \mathrm{Az}$ Erdélyi Múzeumbeli szövegkiadást szóba hozta ugyan, a Heinrich-félét viszont nem. A későbbi szakirodalmi hivatkozásokból kiderül, hogy nagy valószínúséggel Négyesy László monográfiájából vehette át a pályázat kiírásának és lezajlásának adatait, de magát a pályamüvet láthatóan nem ismerte.

A Kazinczy-mű recepciójában a 20. század közepén következett az újabb szakirodalmi áttekintés, méghozzá a kor nagy irodalomtörténeti vállalkozásának, az akadémiai irodalomtörténetne ${ }^{90}$ a keretein belül. A harmadik kötet szerkesztője Pándi Pál, a Kazinczyról szóló fejezetet Szauder József írta. Az életmüben hangsúlyosan helyezte el a Tübingai pályamüvet, és helyét a nyelvújítást előkészítő írások között jelölte ki. Szauder ismerte Heinrich kiadását, a szakirodalmi ajánlóban föl is sorolta, és ez alapján ismertette a pályázat kiírásának körülményeit. Röviden elemezte az egyes fejezeteket, és elsőként hívta föl a figyelmet

\footnotetext{
${ }^{84}$ NÉGYesy László, Kazinczy pályája, Bp., Akadémiai, 1931.

85 Uo., 100-108.

86 Uo., 170.

87 PINTÉR Jenö, Magyar irodalomtörténete, V., Bp., Stephaneum, 1932.

88 Uo., 239.

89 Uo., 281.

90 A magyar irodalom története, I-VI, föszerk. Sötér István, Bp., Akadémiai, 1964-66.
} 
a harmadik, irodalomtörténeti rész fontosságára, amellyel Kazinczy azt bizonyította be, hogy a nyelvünk elérte a fejlettségnek azt a fokát, amely képes a hivatalos nyelv funkcióira. ${ }^{91}$

Az elmúlt évtizedekben Magyarországon ismételten megélénkült a Kazinczy-kutatás. Már a hetvenes évektől kezdődően nemzetközi szinten is dinamikusan újraindult a felvilágosodás korának kutatása, és ez megmutatkozott a magyar tudományos közéletben is. Sorra követték egymást a rangos konferenciák, szakmai tanácskozások, amelyek eredményeit a rendre megjelenő kötetekben olvashatjuk. ${ }^{92} \mathrm{E}$ bonyolult, eszmei-esztétikai áramlatokban rendkívül gazdag korszak kutatásának újabb hazai eredményeit tükrözik azok a fontos monográfiák is, amelyek újabb irányokat jelölnek ki és új értelmezéseket adnak akár a kulcsfogalmaknak is. ${ }^{93}$ Csetri Lajos monográfiájában a nyelvújítást helyezte középpontba, ebben a kontextusban tárgyalta Kazinczy kritikáit mint az aktuális magyar irodalmi életre reagáló írásokat, és ezeknek szerves előzményeként említette meg a Tübingai pályamü fontosságát. Csetri monográfiájában rámutatott arra, hogy Kazinczy számára nem a nyelv, hanem az irodalom fejlettsége volt az elsődleges. Csetri szerint már ebben a pályamunkában valóságos kritikát írt kortársairól, valamint az elődökről, és a pályamủ szintúgy az irodalomtörténész Kazinczy, mint a kritikus Kazinczy véleményét is tartalmazza. ${ }^{94}$

A kilencvenes évek elején Fried István egyik tanulmányában foglalkozott Kazinczy pályamüvével, ${ }^{95}$ pontosabban a pályamunka utolsó, irodalomtörténeti részével. Fried fölhívta a figyelmet arra, hogy Kazinczy mennyire lényegesnek tartotta ezt a munkáját, milyen hosszan küzdött a kiadásáért, és hogy mennyire lényeges volt számára, hogy sikerült legalább az irodalomtörténeti részt megjelentetnie Bécsben, népszerüsítve ezzel a magyar irodalmat.

A Kazinczy-kutatásnak újabb lendületet adott a 2009-es jubileumi magyar nyelv éve, Kazinczy születése 250. évfordulójának az ünnepe. Ebből az alkalomból számos Kazinczyval foglalkozó könyv jelent meg, többek között az októberben, Debrecenben megrendezett emlékkonferencia tanulmánykötete. ${ }^{96} \mathrm{De}$ számos tanulmánykötet, monográfia, tematikus folyóiratszám és szövegkiadás is

${ }^{91}$ A magyar irodalom története, III, szerk. Pándi Pál, Bp., Akadémiai, 1965, 273.

${ }^{92}$ Irodalom és felvilágosodás, szerk. Szauder József, Tarnai Andor, Bp., Akadémiai, 1974; Klasszika és romantika között, szerk. Kulin Ferenc, Margócsy István, Bp., Szépirodalmi, 1990; Folytonosság vagy fordulat?, szerk. Debreczeni Attila, Debrecen, Kossuth Egyetemi Kiad., 1996.

93 Például Csetri Lajos, Egység vagy különbözőség? - Nyelv-és irodalomszemlélet a magyar irodalmi nyelvújitás korszakában, Bp., Akadémiai, 1990; Bínó Ferenc, A felvilágosodás korának magyar irodalma, Bp., Balassi, 1995.

94 CSetri 1995, i. m. 184-186.

${ }^{95}$ FRIED István, Elfelejtett részletek Kazinczy Ferenc magyar irodalomtörténetéböl = Irodalomtörténeti Közlemények, 1991, 597-605.

96 Ragyogni és munkálni, Kultúratudományi tanulmányok Kazinczy Ferencről, szerk. Debreczeni Attila, Gönczy Monika, Debrecen, Debreceni Egyetemi Kiadó, 2010. 
napvilágot látott, ezekből most csak a Tübingai pályamüvet tárgyaló munkákat tekintem át.

Miskolczy Ambrus négykötetes monográfiájának ${ }^{97}$ második kötetében említette meg Kazinczy pályaírását, amikor Kazinczy nemzetszemléletéről értekezik. Miskolczy Kazinczynak Debrecennel való ambivalens viszonyára vetíti rá a pályamü értelmezését. Szerinte ugyanis, bár Kazinczy hadakozott a Debreceni Grammatika ellen, a Tübingai pályamüben mégis arról írt, hogy - a magyar virtus szempontjából - Debrecen talán az egyik legerősebben magyar vidék. ${ }^{98}$ A monográfiában nem igazán magát a pályaművet elemezte és értékelte, sokkal inkább egy szélesebb összefüggés és annak értelmezési tartománya felől közelített a mühöz. Alapkoncepciója szerint ugyanis választott témája, a magyar virtus, a magyar nyelv- és nemzetszemlélet irányából vizsgálta valamennyi Kazinczy-mủvet. Miskolczy szerint Kazinczy Rousseau, Kant és Herder nemzetfelfogásának ihletésére körvonalazta és dolgozta ki a saját elgondolását a nemzetről, melynek alapvető tétele, hogy az európai országok választása ez lehetett: sok nemzet egy nép, vagy sok nép egy nemzet. ${ }^{99}$

Az utóbbi évek Kazinczy-irodalmából kiemelkedik Bíró Ferenc 2010-es nagymonográfiája, amelyben a Tübingai pályamüvel is részletesen foglalkozott. ${ }^{100}$ Elemzésének egyik legfőbb érdeme, hogy módszeresen, összefüggéseiben vizsgálta a teljes szöveget, nem pedig egy kiválasztott nézőpont felől. Bíró ismertette a pályázat kiírásának körülményeit, valamint fölhívta a figyelmet Kazinczy

${ }_{97}$ Miskolczy Ambrus, Kazinczy Ferenc útja a nyelvújítástól a politikai megújulásig, I-IV, Bp., Lucidus, 2009-2010.

${ }_{98}$ Miskolczy 2009-2010, i. m. II, A vitrus jegyében - avagy a széphalmi mester erény-, nyelvés nemzetszemlélete, 76-77.

99 Ezt már egy tanulmányban fogalmazza meg: Miskolczy Ambrus, Kazinczy Ferenc nemzetszemlélete = Kisebbség-kutatás, 2009/3. http://www.hhrf.org/kisebbsegkutatas/kk_2009_03/cikk. php?id=1765 (2015. június 5.) - Meg kell említeni, hogy ennek a tanulmánynak az elején van egy tévedés, Miskolczy Ambrus azt írja, hogy Kazinczy megváltoztatta az eredeti jeligét („Üss, csak hallgass meg!”) arra, hogy „Elég volt 2387 napig!” Ennek a mondatnak nincs értelme, Kazinczy valóban megváltoztatja a jeligét, de arra, hogy „Stolz will ich den Spanier!”, a Schiller Don Carlosából származó mondatra. Miskolczy nem jegyzeteli meg ezt a mondatát, valószínüleg félreolvasta Heinrich bevezetőjét, aki idézi Kazinczy levelét a mottóváltozásról. Viszont két különböző levélről van szó, Kazinczy 1808. május 26-án Prónay Lászlónak írja, hogy „Görög mottómat megváltoztattam. Nékem nem jó a' hatalmas ellenfélnek $\pi \alpha \tau \alpha \xi ̌ o v$-okat kiáltozni. - Elég volt 2387 napig! A’ helyett eggy, már nem élö, Német Irónak versei közzül választottam öt szót. Ezt sem írom-le, attól tartván, hogy a' levél nem jut-el Excellentziádnak kezeihez.” (KazLev V, 466.) Június 2-án Kis Jánosnak már megírja pontosan: „Mottóm megváltozott. A’ helyett Don Carlosból vettem eggy mást, melly unwarscheinlich ugyan, de benne nagy értelem van. Tartsd, kérlek, titokban; tudod mennyi függ attól, hogy az illyeknek mottójok ne ismértessék hamarább mint a' birák a' czédulát felbontják. Im ez az: Stolz will ich den Spanier. Ezt a' Király mondja Pózának. Oda czélzok vele, hogy az Uralkodó örülhet, hogy bennünk hazaszeretet lobog, mellynek eggy része a' nyelv' szeretete." (KazLev V, 472.)

${ }^{100}$ Bíró Ferenc, A legnagyobb pennaháború, Kazinczy Ferenc és a nyelvkérdés, Bp., Argumentum, 2010, 428-436. 
egyéni szövegszerkesztésére, amellyel - gyakorlatilag - megváltoztatta a pályázat kérdéseinek súlypontját. Bíró az irodalmi antológia szerepét is hangsúlyosan tárgyalta. Véleménye szerint Kazinczy azért illusztrálta a nyelv fejlettségét az irodalom nyelvével, mert a nyelv gazdagságának bizonyítására vitathatatlanul ez a nyelvi felület látszik a legalkalmasabbnak, ugyanakkor ez az a közeg, amelyben a nyelvi változások a leginkább létrehozhatóak és érvényesíthetőek. Bíró Ferenc ezen túl azonban nemcsak a Kazinczy-életmüben helyezte el a pályamüvet, hanem történeti összefüggésében is. Szerinte Kazinczy munkája folytatja a felvilágosult rendiség előző nemzedékének tendenciáit, de már - a nemzetiségekkel szemben - jóval toleránsabb fölfogásban.

A Kazinczy-szövegek, így a Tübingai pályamü recepciójának módszeres és szisztematikus kutatása aktívan rendezheti át egyes résztémák érvényesebb átértékelését és újraértelmezését.

\section{AJKAY, ALINKA}

\section{„En vue d'élever le statut de la langue hongroise"}

\section{L'histoire des éditions et de la réception de l'ouvrage de Kazinczy écrit pour le concours de Tübingen}

La seule édition complète de L'ouvrage pour le concours de Tübingen a vu le jour en 1916, il y donc un siècle. La plupart des spécialistes semblent admettre la reconstruction que l'éditeur a proposée des circonstances de la création du texte en question. Or, à force de revoir de près l'écho critique de l'édition, ainsi que la fortune des manuscrits de Kazinczy, quelques affirmations de Gusztáv Heinrich nous paraîtront bien incertaines et contestables. Il nous semble par conséquent indispensable de revoir un certain nombre de convictions transmises jusqu'à aujourd'hui par les générations successives de chercheurs. Dans notre étude, nous nous efforcerons de mettre en relief quelques faits et quelques intuitions qui sont dignes de faire leur retour dans le canon de la recherche kazinczyenne. Du vivant de son auteur, le texte complet de L'ouvrage pour le concours de Tübingen n'a jamais vu le jour, ni en allemand, ni en hongrois. Seule l'anthologie littéraire qui constitue la troisième partie fut imprimée en 1814. Ceci est bien étrange, vu que Kazinczy n'a nullement dissimulé sa volonté de voir publié cet ouvrage consacré á la cause de la langue hongroise. L'étude attentive de la réception - longue de deux siècles - de L'ouvrage pour le concours de Tübingen nous permet d'identifier des phases dans le processus. L'édition de 1916 fut suivie de quelques comptes-rendus importants, dont le plus important est sans doute celui d'Ödön Simai. Dans son texte, Simai évoque quelques aspects importants (négligés par Heinrich) de la question, comme par exemple le fait que l'auteur de la traduction allemande envoyée au concours n'est autre que Kazinczy lui-même, par contre, une partie du texte hongrois, publié en fragments, est selon toute probabilité l'oeuvre de Pál Szemere. Simai a identifié ainsi un élément central de la problématique des manuscrits et de l'édition critique de l'ouvrage en question. La recherche ne peut pas se permettre de négliger ses remarques et son argumentation.

Keywords: Hungarian language, history of ideas, $19-20^{\text {th }}$ centuries, editions history, Kazinczy Ferenc, Szemere Pál 